\title{
Review of Prudential Public Leadership: Promoting Ethics in Public Policy and Administration. By John Uhr. New York: Palgrave Macmillan, 2015.
}

\section{Citation}

Winston, Kenneth. 2016. "Review of Prudential Public Leadership: Promoting Ethics in Public Policy and Administration. By John Uhr. New York: Palgrave Macmillan, 2015." Perspectives on Politics 14 (01) (March): 223-224. doi:10.1017/s1537592715003710.

\section{Published Version}

https://doi.org/10.1017/S1537592715003710

\section{Permanent link}

http://nrs.harvard.edu/urn-3:HUL.InstRepos:30248832

\section{Terms of Use}

This article was downloaded from Harvard University's DASH repository, and is made available under the terms and conditions applicable to Other Posted Material, as set forth at http:// nrs.harvard.edu/urn-3:HUL.InstRepos:dash.current.terms-of-use\#LAA

\section{Share Your Story}

The Harvard community has made this article openly available.

Please share how this access benefits you. Submit a story.

\section{Accessibility}




\section{Prudential Public Leadership: Promoting Ethics in Public Policy and}

Administration. By John Uhr. New York: Palgrave Macmillan, 2015. 202p. \$105.

\section{Kenneth Winston, Harvard Kennedy School}

John Uhr has written a rich and challenging work of political philosophy for public leaders, to demonstrate the relevance of political philosophy to practitioners in democratic societies. Specifically, he aims to retrieve Aristotle, to restore Aristotle's rightful place among theorists of the ethics of leadership. Aristotle, Kant, and J. S. Mill represent paradigmatic expressions of the three theoriesutilitarianism, deontology, and virtue theory—that Uhr says dominate the ethical reflection of practitioners today. But Aristotle is first among equals, in his view, because elements of his theory show how the other two theories are to be deployed and brought into a unified whole.

Why Aristotle? Alone among virtue theorists, Aristotle carves out a special place for rhetoric and prudence: "rhetoric is the external face and prudence is the internal mind of leadership" (26). Accordingly, Uhr begins with chapters on rhetoric and prudence before getting to the main chapters on Mill, Kant, and Aristotle. Rhetoric is important because leaders "have colleagues and followers who need to be convinced of the merits" of what the leader is doing or proposes to do (34). Importantly, the skill of being persuasive is as difficult as it is crucial, for it requires knowing what to shield from the public as much as what to broadcast (26). Thus, rhetoric must be guided by prudence. While rhetoric aims to enhance trust and confidence, this goal is achieved only by careful management of what is said. 
Prudence operates like the CEO of a corporate entity, performing a core executive function. Neither utilitarianism nor deontology knows "how much, or indeed how little, a political community here and now requires" of it (54). Prudence makes that decision; it decides when cost/benefit calculation or appeal to high principle is appropriate. "The trick is to know what each form of ethics is good at, and what it is not good at" (55), so that leaders can do what is right in specific circumstances. Thus, prudence manages the other theories and blends the best in them $(83,126)$. Ethical leaders choose values flexibly according to time and place; the critical challenge is explaining or justifying one's choice so as to maintain the trust and confidence of others (57).

In the opening chapters, Uhr also presents four vignettes, each a few paragraphs to a few pages in length, to illustrate his central themes. They include FDR's fireside chats and Martin Luther King Jr.'s "I Have a Dream" speech to illustrate the effective use of rhetoric; Abraham Lincoln's behind-the-scenes efforts to win Congressional approval of the $13^{\text {th }}$ amendment to illustrate prudential leadership; and Winston Churchill's authorization of deliberate terror bombing of civilian populations, as in Dresden, to illustrate dirty hands. What is striking here is that the vignettes feature high-level political figures, mostly presidents and prime ministers. This is curious because Uhr makes clear in the opening chapter that his intended audience consists of public administrators (bureaucrats and civil servants), especially those who work within a parliamentary system, whose opportunities for ethical agency are quite limited. He says later that the core of leadership ethics is the relationship between politicians and bureaucrats (171), but 
he does not offer an extended story of a bureaucrat or civil servant struggling with a difficult ethical issue. We do not see a public administrator attempting to apply the principles learned from the three philosophers.

After the chapter on prudence and before discussing the three philosophers, Uhr devotes a chapter to dirty hands. This is a bit of a puzzle. Initially, it seems he intends to highlight the moral significance of prudence as a virtue. He says, for example, that we have to recognize that "awful challenges" arise where leaders have to use "dishonorable means, such as public deception, to achieve honorable ends" (27). Also, whether dirty hands are acceptable depends on whether leaders can make a convincing case for them (58). In the end, however, Uhr remains ambivalent. The bulk of the chapter discusses Machiavelli, Weber, and Hegel, which are good choices, but their arguments are not endorsed. I am more inclined than Uhr to regard Machiavelli's reflections on leadership in a positive light, but of the three Weber is the most important, since he spells out more clearly than the others the reasons why the problem of dirty hands has to be taken seriously.

Uhr is apparently not aware of the uncertainty among philosophers about what counts as a dirty hands case. This is evident in his vignettes of Churchill and Lincoln. I have not come across a single philosopher who takes the bombing of Dresden as an example of dirty hands; it was simply wrong. (For many years, a story circulated about Churchill and Coventry, but it turned out the facts were mistaken.) Lincoln's machinations regarding the $13^{\text {th }}$ amendment are another matter. (I wrote about Lincoln in a 1994 essay on dirty hands.) Unfortunately, Uhr relies solely on Stephen Spielberg's film Lincoln; he has not consulted the work of 
historians. Not surprisingly, the Hollywood production simplifies the story and omits the principal ethical dilemma (a corrupt vote in the old Congress or a clean vote in the new Congress six weeks later), in order to present Lincoln in a certain agreeable light. Is Uhr reluctant to admit openly that leaders may have to get their hands dirty? This is a reasonable question because Uhr often suggests that great leaders are superior people who grasp what their role requires but have to explain themselves to audiences who lack the capacity to fully understand (e.g., 136). The prudent leader sometimes hides and dissembles.

And, apparently, so does the prudent theorist of leadership, such as Henry Sidgwick (84-86, 96-100) and perhaps Kant (115-118). I do not have space to discuss Uhr's often illuminating reflections on the three major theorists; instead I will highlight the underlying claims: (1) theory enters when leaders attempt to explain their conduct publicly (23); (2) the theories leaders appeal to are the three familiar ones (7); and (3) the importance of theory is evident when leaders disagree about policies or practices, because theory assists in adjudicating such disagreements (24). I have to say I am skeptical. My experience suggests that, when leaders offer justificatory accounts, their repertoire is much broader, including cultural, religious, and political ideals that do not fit easily into the three theories. And the three theories are not very useful in adjudicating disputes, since they themselves are highly contested. By not examining ethical reasoning "as it really is through the eyes of practical leaders" (80), and instead turning to the writings of certain "great thinkers," I believe Uhr has missed an opportunity to illuminate the real world of leadership. 
Still, I think Uhr is on the right track in highlighting the central place of prudence in public ethics. Most importantly, he recognizes the gap between principle and action. When a practitioner asks "What should I do in these circumstances?," the question is strategic, and the answer must take account of what is feasible and what authority the practitioner has, as well as what consequences are likely to ensue for specific individuals. The answer is guided by principles, but what it means to be guided by principles is not straightforward. To guide is not necessarily to determine. The prudential leader knows the limits of abstract theory and the dangers of ideology.

In his two concluding chapters, Uhr presents a few more vignettes, along with a set of "talking points," to review his main themes. Of the stories, the most interesting (to my mind) features the unsuccessful efforts of an Australian health minister's chief of staff pressuring a civil servant to dismantle a consumer website on the health risks of certain foods. Despite his government position, the chief of staff has continued to act as a lobbyist for business firms adversely affected by the website and thus has a clear conflict of interest. What is remarkable is that Uhr says almost nothing about the civil servant who refused to cave in to the pressure. How did she think about her actions? What principles, if any, did she appeal to? Did personal as well as professional ideals play a crucial role? Here is a courageous public servant I would like to learn more about. 